\title{
PERFORMANCE AND EMISSION ANALYSIS OF DIESEL ENGINE USING THERMAL BARRIER COATING AND ADDITION OF CERIUM OXIDE NANOPARTICLES TO PALM BIODIESEL
}

\author{
THIRUSELVAM, $\mathrm{K}^{\star}$ and GANESH, $\mathbf{V}$ **
}

\begin{abstract}
This work investigates the effect of thermal barrier coating and addition of cerium oxide nanoparticles to the palm biodiesel fuelled diesel engine. The combustion chamber parts of cylinder liner and piston were coated 200 and 100 micron thickness respectively using equal percentages of Yittria Stabilised Zirconia (YSZ) and alumina powder in plasma spraying technique. The 30 ppm and 60 ppm of cerium oxide (IV) nanoparicles were added to the palm biodiesel fuel separately. The performance and pollution parameters were analysed initially using a thermal barrier coated (TBC) engine with neat palm biodiesel. Cerium oxide (IV) nanoparticles were then added to the palm biodiesel and their effects were compared with the base engine. The final performance results showed reduction in the specific fuel consumption on an average of $11.86 \%, 16.92 \%$ and $20.57 \%$, while brake thermal efficiency was increased by $3.21 \%, 4.28 \%$ and $4.82 \%$ in neat palm biodiesel fuel, $30 \mathrm{ppm}$ and $60 \mathrm{ppm} \mathrm{CeO}_{2}$ mixed palm biodiesel fuel used TBC engine respectively. Carbon monoxide and unburned hydrocarbon emission were reduced by $2.2 \%$ and $3.7 \%$ and nitrogen oxide emission was increased by $1.7 \%$ for TBC engine. However, the use of oxygen denoting catalyst of cerium oxide nanoparticles caused a $2.4 \%$ reduction in nitrogen oxide emission.
\end{abstract}

Keywords: thermal barrier coating (TBC), cerium oxide nanoparticle, diesel engine, cylinder liner.

Date received: 7 April 2018; Sent for revision: 14 May 2018; Received in final form: 30 July 2018; Accepted: 5 December 2018.

\section{INTRODUCTION}

Wear resistive and thermal barrier ceramic coating plays a vital role in the combustion and performance of diesel engines. Advancement in industrial engines produce a high power to weight ratio, cheap manufacturing cost and highly

\footnotetext{
Department of Mechanical Engineering,

Panimalar Engineering College, Bangalore Trunk Road,

Varadharajapuram Nazarethpettai, Poonamalle,

600123 Chennai, Tamil Nadu, India.

E-mail: thirumurugu2014@gmail.com

** Department of Automobile Engineering,

Sri Venkateshwara College of Engineering,

Chennai-Bengaluru High Road, Pennalur Village,

Sriperumpudur, 602117 Chennai, Tamil Nadu, India.
}

robust in nature. The implications of wear through corrosion, thermal aspects and mechanical loads, leads to power loss and engine seizing with a loads of hazardous emissions to the environment. Without engine or oil modification major issues, such as injector sticking and blocking which prevent engine operation, occurs when using pure vegetable oils in diesel engine (Yuvarajan et al., 2016a). Improvement of lubricate conditions on engine components, leads to the frictional losses in engines. One such method is, reducing the frictional wear through coatings on piston rings. Secondary wear propagates, through spalling wear on piston crown through high combustion pressure and temperature. Yittria Stabilised Zirconia (YSZ) has the advantages of high thermal expansion coefficient, low thermal 
conductivity and high thermal shock resistance, it also has the drawbacks of sintering above $1473 \mathrm{~K}$, phase transformation occurring at $1443 \mathrm{~K}$, corrosion and oxygen-transparent. Alumina has advantages of high corrosion-resistance, high hardness and absence of oxygen-transparency. But it has the disadvantages of phase transformation occurring at $1273 \mathrm{~K}$, high thermal conductivity and very low thermal expansion coefficient (Pandian et al., 2017). So YSZ and alumina coating cannot individually be the best thermal barrier coating materials. Hence, the authors have used alumina and YSZ in equal proportion as coating material in the cylinder liner and piston. Thermal barrier coating materials have high melting point, low thermal conductivity, low density, high resistance to thermal shock, confrontation to oxidation and chemical environment, high surface emissivity, ability to withstand mechanical erosion and high coefficient of thermal expansion. The ceramic-coated engines produce better thermal efficiency and are known for low emission level (Devarajan et al., 2018a, b). Plasma spraying thermal barrier coating is the best method for coating a diesel engine combustion chamber. Cerium oxide promotes the oxidation for reduction of $\mathrm{CO}$ emission and absorbs oxygen for reduction of $\mathrm{NO}_{\mathrm{x}}$ emission (Yuvarajan et al., 2016b; Devarajan et al., 2018c). It also burns off the carbon particles deposited in the cylinder wall region which results in reduction of the $\mathrm{HC}$ emission (Velliyan et al., 2017).

\section{MATERIALS AND METHODS}

\section{Method of Coating of Cylinder Liner and Piston}

There are various thermal barrier coating methods available for coating the internal combustion chamber in an engine. The methods vary according to the characteristics of materials used. The plasma spraying thermal barrier coating is the best method for coating a diesel engine combustion chamber. A cylinder liner was internally machined for applying coating to thickness of 200 micron using $\mathrm{CNC}$ lathe machine. Then the liner was coated to the respective thickness using the plasma spraying process and finally excess thickness of coatings were removed again using a CNC lathe machine. The piston was coated to 100 micron thickness directly without any machining. The cylinder liner and piston were coated by $8 \%$ YSZ and alumina with equal percentage. Table 1 shows the plasma spraying equipment process parameters while Figures 1 and 2 provide details of the composition of the materials of $\mathrm{Al}_{2} \mathrm{O}_{3}+\mathrm{YSZ}$ and deposition of thermal barrier coating powder on the base metal.

Figures 3 and 4 are pictures of a piston and a cylinder liner before and after coating with equal percentages of $8 \%$ YSZ and alumina thermal barrier coating using plasma spraying technique.

\section{Mixing of Cerium Oxide Nanoparticles with Palm Biodiesel}

Cerium oxide nanoparticles of size less than 25 $\mathrm{nm}$ were used in this investigation. Cerium oxide nanoparticles were purchased from Sigma-Aldrich, USA. The specifications of the nanoparticles are listed in Table 2. The samples of cerium oxide 30 ppm and 60 ppm were separately mixed with 1 litre palm biodiesel and placed in an ultrasonicator set at a frequency of $40 \mathrm{kHz}$ and $120 \mathrm{~W}$ for 15 min for proper mixing of nanoparticles with palm biodiesel.

Nanoparticle in nano powder form ( $\mathrm{ZnO}$, alpha, $98+\%, 50 \mathrm{~nm}$ ) were mixed with neat palm biodiesel (M100) at different dosage level by mass basis. Ultrasonicator with a frequency of $40 \mathrm{kHz}$ and 120 $\mathrm{W}$ for $15 \mathrm{~min}$ for proper mixing of nanoparticles with palm biodiesel and also to ensure homogenous emulsion. Fuel containing nanoparticle is further mixed and stirred with surfactant (Span-80) using magnetic agitator for $60 \mathrm{~min}$ at a speed of $510 \mathrm{rpm}$ in atmospheric conditions to improve the bonding between nanoparticle and fuel.

TABLE 1. PROCESS PARAMETER OF PLASMA SPRAYING

\begin{tabular}{llll}
\hline S1. No. & Parameters & Value \\
\hline 1 & Spray gun & $3 \mathrm{MB}$ & \\
2 & Nozzle & GH & \\
3 & Current $(\mathrm{A})$ & $490-500$ & \\
4 & Voltage $(\mathrm{V})$ & $60-70$ & \\
5 & Powder feed $\left(\mathrm{g} \mathrm{min}^{-1}\right)$ & $40-50$ & \\
6 & Spray distance & $7.6 \mathrm{~m}-12.7 \mathrm{~m}(3-5$ inch) & \\
7 & Particle velocity $\left(\mathrm{m} \mathrm{s}^{-1}\right)$ & Up to 450 & \\
8 & Arc temperature $\left({ }^{\circ} \mathrm{C}\right)$ & 16000 & Flow rate (SCFH) \\
9 & Particle size $(\mu \mathrm{m})$ & $20-100$ & $80-90$ \\
10 & Inert gas flow & Pressure $(\mathrm{psi})$ & $20-25$ \\
& a) Argon & $100-120$ & \\
\hline
\end{tabular}

Note: SCFH - standard cubic feet per hour. 


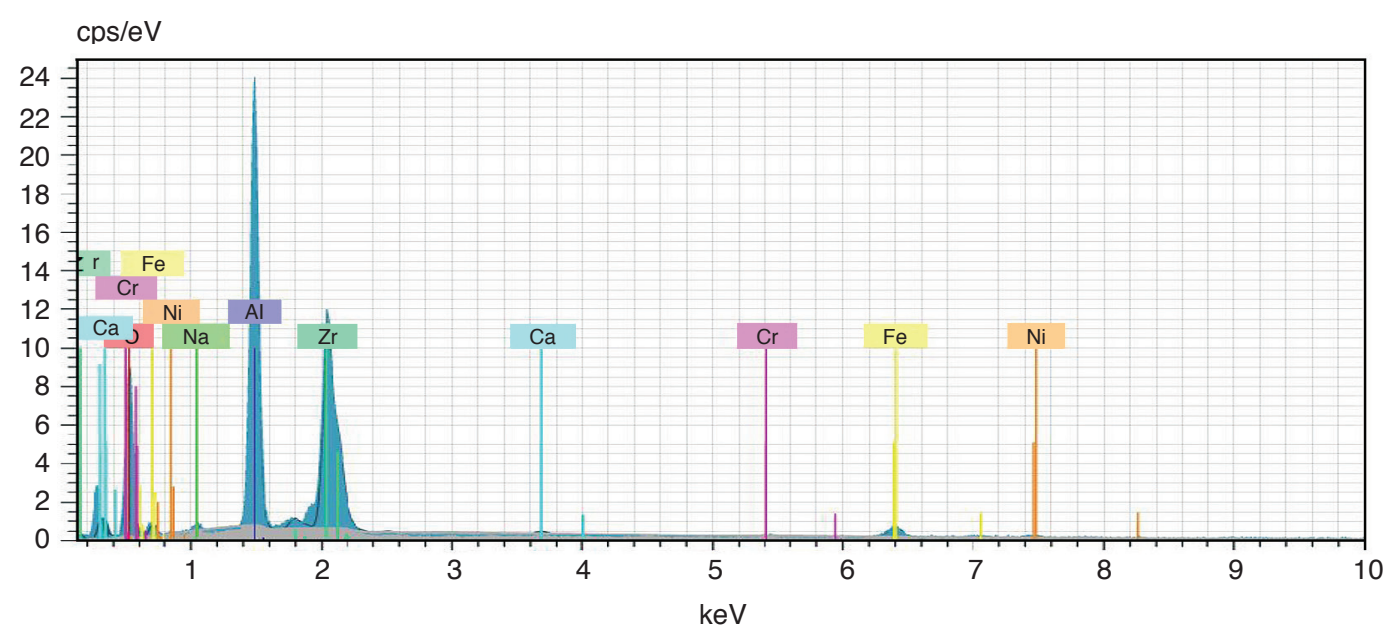

Figure 1. EDX results of $\mathrm{Al}_{2} \mathrm{O}_{3}+Y S Z$ (Yittria Stabilised Zirconia).

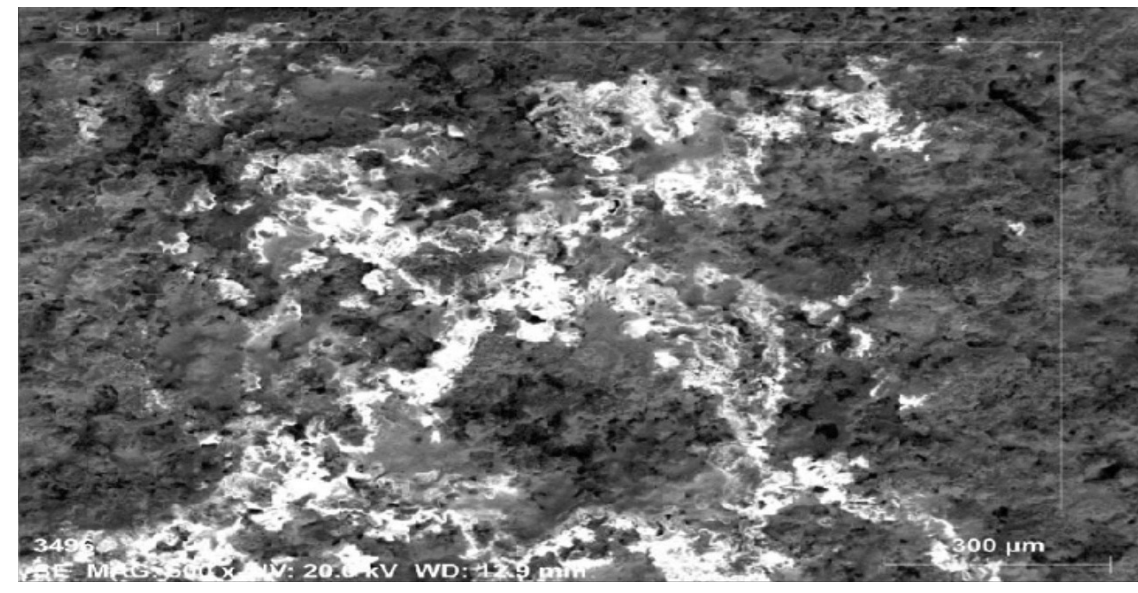

Figure 2. Scanning electron microscopy (SEM) image of $\mathrm{Al}_{2} \mathrm{O}_{3}+Y S Z$ (Yittria Stabilised Zirconia).

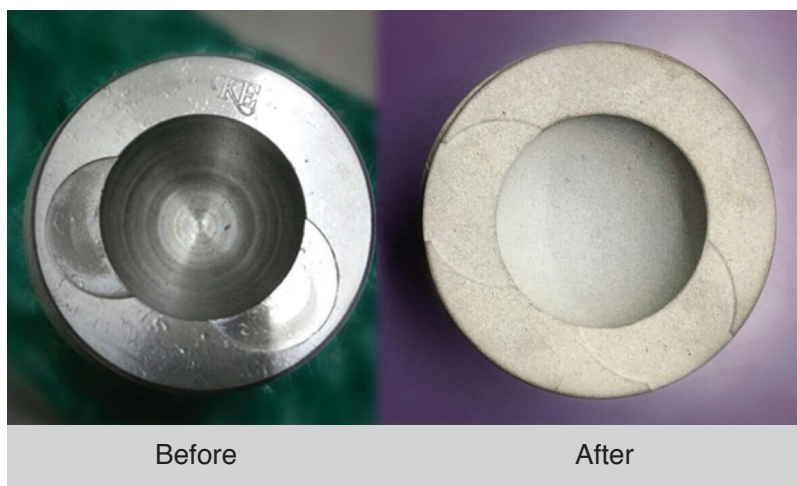

Figure 3. Piston before and after coating.

TABLE 2. CERIUM OXIDE SPECIFICATIONS

\begin{tabular}{ll}
\hline Item & Specification \\
\hline Manufacturer & $\mathrm{M} / \mathrm{s}$ Sigma-Aldrich,USA \\
Product number & 544841 \\
CAS number & $1306-38-3$ \\
Formula & $\mathrm{CeO}_{2}$ \\
Formula weight & $172.11 \mathrm{~g} \mathrm{~mol}^{-1}$ \\
Appearance (colour) & White to yellow \\
Appearance form & Powder \\
Size & $\leq 25 \mathrm{~nm}$ \\
\hline
\end{tabular}

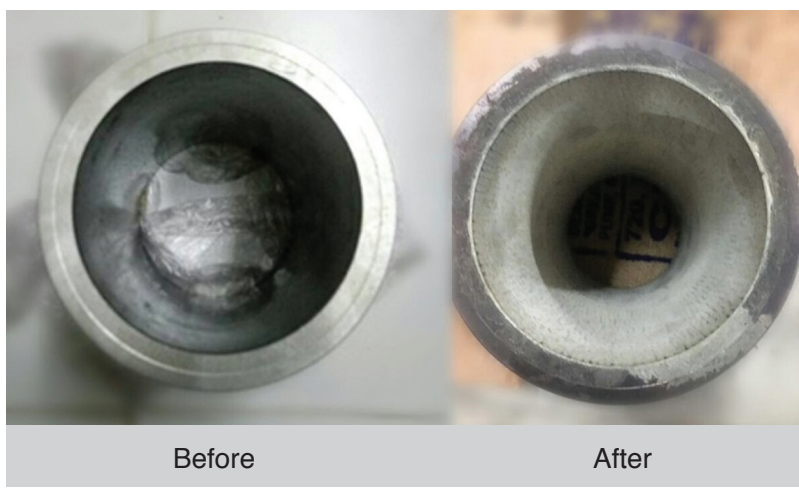

Figure 4. Cylinder liner before and after coating.

\section{Experimental Set-up}

Fuel tests was performed on a four-stroke single cylinder, air cooled type, naturally aspirated, DI (direct injection) diesel engine (AV1, Kirloskar model). The experimental set-up with its schematic diagram is depicted in Figure 5 and the test system consisted of an engine, a dynamometer, fuel supply system, data acquisition unit, emission analyser and a smoke opacimeter. The engine under testing was 


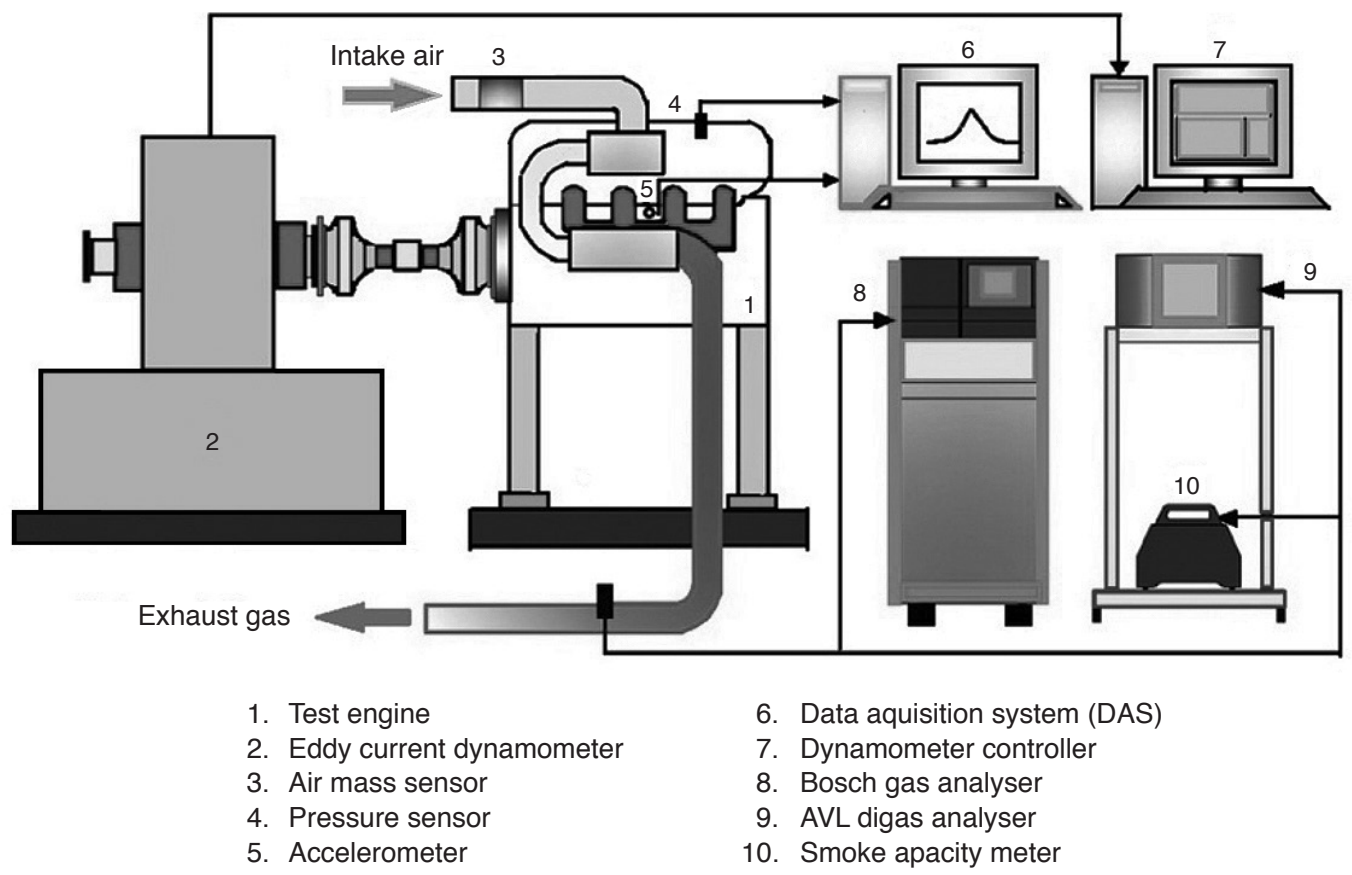

Figure 5. Engine dynamometer set-up.

coupled to a dynamometer of eddy-current type (Dynalec make) along with an electronic exciter for measuring and adjusting the load. For the fuel consumption measurement, the time required for 100 cc of fuel consumption was recorded with the aid of burette set-up and stop watch. The exhaust gas and engine oil temperature were obtained by a K-Type Thermocouple which was connected to the digital display unit. For collecting the exhaust gas samples a measuring probe was connected to the exhaust tail pipe of the engine. The collected emissions of $\mathrm{HC}$, $\mathrm{NO}_{x}, \mathrm{CO}_{2}$ and $\mathrm{CO}$ were obtained by using the AVL make (AVL digas 444 model) emission analyser and similarly smoke opacity by using AVL 437C model opacimeter. Before conducting the experiments, the gas analysers were calibrated using standard gases (Table 3). The combustion chamber pressure was obtained using a Kistler make miniature pressure transducer which was connected to computer-based data acquisition system (DAQ). The degree of crank angle as well the position of TDC (top dead centre) was obtained using an encoder regarding crank angle. The acquired output data was fed into the combustion analysis software (AVL INDMICRA) with the aid of DAQ system. The combustion analyser provides the results of the characteristics of combustion such as in cylinder gas pressure variation, HRR (heat release rate), peak pressure, and ignition delay period of tested fuel samples. Repeating the same for 100 cycles to obtain all the parameters and considering the average of all these values was taken to reduce the influence of cycleby-cycle variation. All these investigations were performed at steady state conditions in order to ensure reliability of recordings. Before the readings are acquired, the engine was made to run for about 15 min to allow it to stabilise. In order to ensure the correctness in the engine testing each test should repeat three times and the averaged results are mentioned in the subsequent section. Uncertainty analysis was performed to evaluate the accurateness of engine performance measurements.

The performance of the uncoated engine and combustion parameters were initially noted. The base engine cylinder liner and piston were then replaced by a 200 micron thickness TBC coated cylinder liner and a 100 micron thickness TBC at the top of the piston. TBC engine performances and combustion parameters were noted in the next using palm biodiesel a fuel. Finally, TBC engine performance and combustion parameters were noted after using $30 \mathrm{ppm}$ and $60 \mathrm{ppm}$ cerium oxide nanoparticles that were added separately with 1 litre of palm biodiesel. All the performances and combustion parameters were recorded in an engine with compression ratio of 17.5 .

\section{RESULT AND DISCUSSION}

Experimental investigations were performed at different loading condition varied from $0 \%$ to $100 \%$ and each reading was taken under conditions of steady state. All required characteristics were analysed by a TBC engine with neat palm biodiesel fuel, $30 \mathrm{ppm}$ and $60 \mathrm{ppm}$ cerium oxide mixed palm biodiesel fuel in the TBC engine with a base engine for various load conditions. 
TABLE 3. GAS ANALYSER RANGE, ACCURACY AND UNCERTAINTIES DETAILS

\begin{tabular}{lll}
\hline Quantity & Range & Accuracy \\
\hline $\begin{array}{l}\text { Piezo sensor } \\
\text { Crank angle sensor }\end{array}$ & $5000 \mathrm{psi}$ & - \\
Data acquisition device & NI USB-6210, 16-bit, $250 \mathrm{kS} \mathrm{s}{ }^{-1}$. & - \\
Temperature sensor type & & \\
$\quad$ RTD & Input $-0^{\circ} \mathrm{C}-100^{\circ} \mathrm{C}$ & $\pm 1^{\circ} \mathrm{C}$ \\
PT100 & Input $-0^{\circ} \mathrm{C}-100^{\circ} \mathrm{C}$ & $\pm 1^{\circ} \mathrm{C}$ \\
Thermocouple & Input $-0^{\circ} \mathrm{C}-1200^{\circ} \mathrm{C}$, & $\pm 1^{\circ} \mathrm{C}$ \\
& Output $-4-20 \mathrm{~mA}$ & \\
Load indicator digital & $0-50 \mathrm{~kg}, \mathrm{supply} 230 \mathrm{~V} \mathrm{AC}$ & - \\
Load sensor & & - \\
$\quad$ Load cell type strain gauge & $0-50 \mathrm{~kg}$ & $\pm 1 \mathrm{~mm} \mathrm{WC}$ \\
Fuel flow transmitter, DP transmitter & $0-500 \mathrm{~mm} \mathrm{WC}$ & $\pm 1 \mathrm{~mm} \mathrm{WC}$ \\
Air flow transmitter, pressure transmitter & $0-250 \mathrm{~mm} \mathrm{WC}$ & \\
\hline
\end{tabular}

\section{Specific Fuel Consumption}

Brake specific fuel consumption (SFC) was the fuel required for the internal combustion engine in order to produce the output in terms of unit power (Radhakrishanan, 2017). Variations in SFC of the TBC engine with neat palm biodiesel, $30 \mathrm{ppm}$ and $60 \mathrm{ppm}$ cerium oxide nanoparticles mixed palm biodiesel fuel used TBC engine results have been plotted in Figure 6.

There was a substantial reduction in the SFC for $\mathrm{TBC}$ engine at an average of $11.86 \%$. It is due to high combustion temperature maintained in the combustion chamber employing YSZ and alumina thermal barrier coating materials which result in reduced the heat flow from combustion chamber (Pandian et al., 2017). In addition, $30 \mathrm{ppm}$ and 60 ppm cerium oxide mixed palm biodiesel used in TBC engine caused a reduction in fuel consumption on an average of $16.92 \%$ and $20.57 \%$, respectively (Pandian et al., 2018). Cerium oxide promotes the combustion process further and causing a reduction

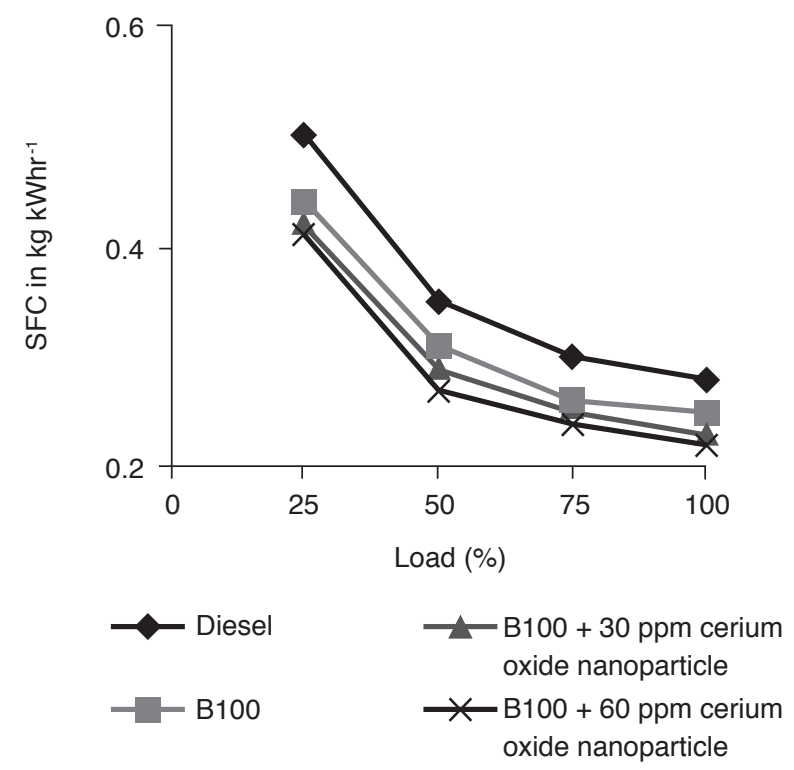

Figure 6. Specific fuel consumption of test fuels with load. in the rate of fuel consumption (Vellaiyan and Amirthagadeswaran, 2017). This decrease in the SFC showed the efficient use of the supplied fuel by the cerium oxide mixed fuel used TBC engine for the accomplishment of the work.

\section{Brake Thermal Efficiency}

Brake thermal efficiency (BTE) commonly known as fuel conversion efficiency, an indication of useful power derived from chemical energy of the fuel (Mahalingam et al., 2018). Higher thermal efficiency from the engine indicates better fuel economy and conversion efficiency from the fuel (Mahalingam et al., 2018). Variations in BTE of the TBC engine with neat palm biodiesel, $30 \mathrm{ppm}$ and $60 \mathrm{ppm}$ cerium oxide nanoparticles mixed palm biodiesel fuel used TBC engine results have been plotted in Figure 7.

The BTE increased on an average of TBC engine, $30 \mathrm{ppm}$ and $60 \mathrm{ppm}$ cerium oxide mixed palm biodiesel fuel used TBC engine as $3.21 \%, 4.28 \%$

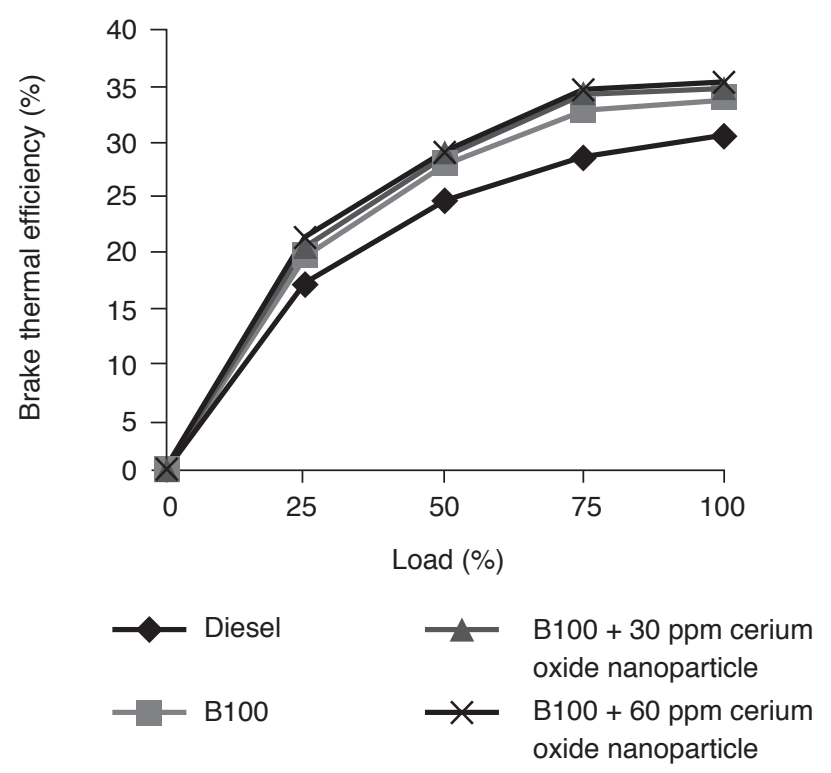

Figure 7. Brake thermal efficiency of test fuels with load. 
and $4.82 \%$, respectively. YSZ having low thermal conductivity and high thermal expansion coefficient provided better insulation to combustion chamber, thereby heat rejection to cooling waterside was low. It caused improvement in the BTE of the engine. The cerium oxide added enhanced the BTE by the follow-up action of micro explosion and secondary atomisation of nanoparticles. The atomisation of nanoparticles provides higher surface area to volume ratio, thereby enhanced catalytic combustion caused to improve the BTE (Venkata Ramanan and Yuvarajan, 2016).

\section{Carbon Monoxide Emission}

Figure 8 shows carbon monoxide emission variation in neat palm biodiesel, $30 \mathrm{ppm}$ and $60 \mathrm{ppm}$ cerium oxide nanoparticles mixed palm biodiesel used TBC engine with different load conditions (Joy et al., 2017; Kishore Pandian et al., 2017). Carbon monoxide emission variation levels are minimum in low load conditions and high at full load condition. Carbon monoxide emission decreases in percentage of volume in the neat palm biodiesel, $30 \mathrm{ppm}$ and 60 ppm cerium oxide nanoparticles mixed palm biodiesel used TBC engine on an average as $0.0276 \%$, $0.0436 \%$ and $0.0528 \%$ respectively compared with a base engine. Carbon monoxide emission is produced mainly due to insufficient oxygen and incomplete combustion. The TBC engine was maintained at high combustion chamber temperature, thereby incomplete combustion was less and cerium oxide promotes oxidation process in the combustion reaction reduced insufficient oxygen in the combustion chamber (Devarajan and Madhavan, 2017). Therefore, carbon monoxide emissions were reduced to a low level in all load conditions of TBC engine compared with base engine.

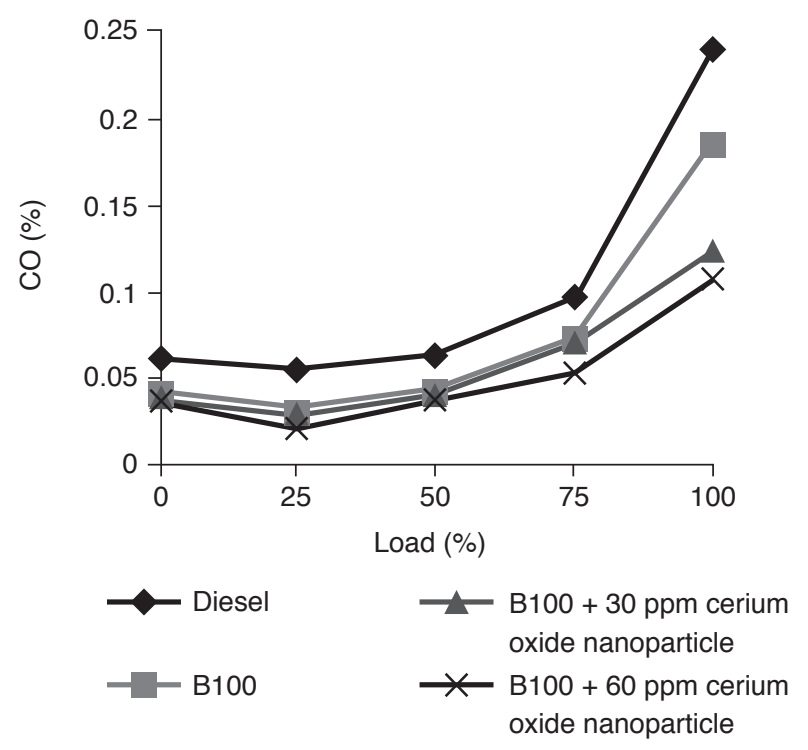

Figure 8. Variations in carbon monoxide emission for test fuels with load.

\section{Hydrocarbon Emission}

Variations of unburned hydrocarbon emission are shown in Figure 9. It shows TBC engine emission level as very low when it is run by neat palm biodiesel and cerium oxide nanoparticles mixed palm biodiesel used conditions compared with base engine (Anbarasu et al., 2015). Unburned hydrocarbon emissions were reduced compared with a base engine on an average of 14, 21.4 and 26 ppm in neat palm biodiesel, 30 ppm and 60 ppm cerium oxide mixed palm biodiesel used TBC engine respectively (Anbarasu and Karthikeyan, 2016). This reduced hydrocarbon emission happened due to TBC engine maintaining a high heat energy in the chamber, it absorbed deposits of oil in the combustion chamber wall, usage of one of thermal barrier coated material of alumina and cerium oxide nanoparticles promotes the oxidation process with hydrocarbon (Pandian et al., 2017).

Hydrocarbon combustion of $\mathrm{CeO}_{2}$ :

$(2 \mathrm{x}+\mathrm{y}) \mathrm{CeO}_{2}+\mathrm{C}_{\mathrm{x}} \mathrm{H}_{\mathrm{y}} \rightarrow[(2 x+y) / 2] \mathrm{Ce}_{2} \mathrm{O}_{3}+$

$x \mathrm{CO}+(\mathrm{y} / 2) \mathrm{H}_{2} \mathrm{O}$

Soot burning:

$4 \mathrm{CeO}_{2}+$ Csoot $\rightarrow 2 \mathrm{Ce}_{2} \mathrm{O}_{3}+\mathrm{CO}_{2}$

Oxidation catalyst of cerium oxide promotes the complete combustion by enhancing hydrocarbon oxidation due to lower carbon combustion activation temperature. Hence, nanoparticles lead to further reduced hydrocarbon emissions.

\section{Nitrogen Oxide Emission}

Nitrogen oxide emission variations under various test condition are shown in Figure 10. It

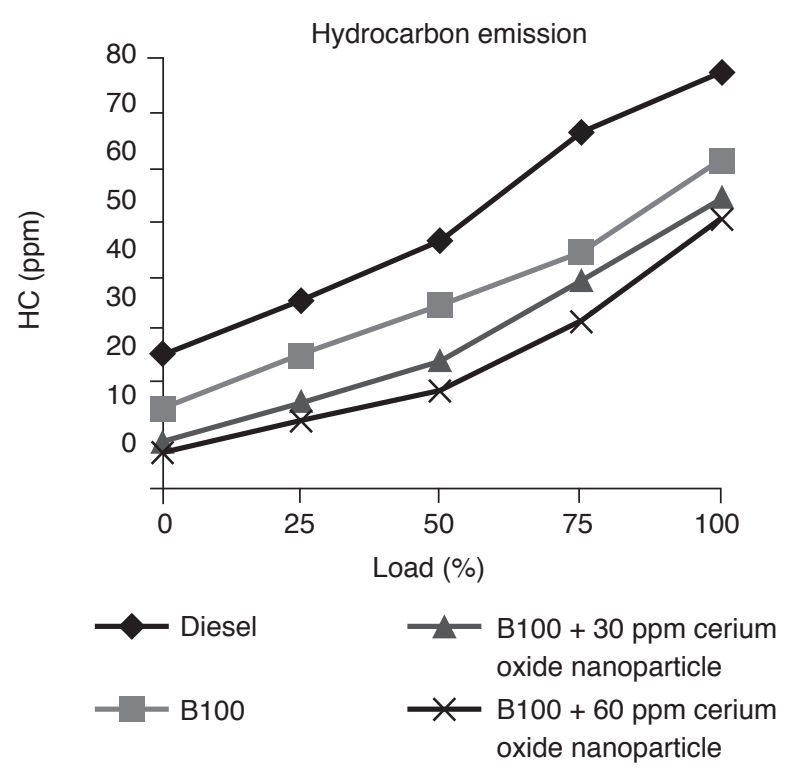

Figure 9. Variations in hydrocarbon emission for test fuels with load. 
indicates neat palm biodiesel used in TBC engine producing higher $\mathrm{NO}_{x}$ emission compared to the uncoated engine (Arul Gnana Dhas et al., 2018). It is due to TBC engine maintaining higher combustion temperature restricted to dissipation of heat energy to cooling water. TBC engine was seen increasing gas temperature by $40^{\circ} \mathrm{C}$ to $50^{\circ} \mathrm{C}$ in the combustion chamber compared with uncoated engine. However, there was a reduction in this nitrogen oxide emission by addition of $30 \mathrm{ppm}$ and $60 \mathrm{ppm}$ cerium oxide nanoparticles mixed palm biodiesel on an average of 84 ppm and 114.14 ppm, respectively compared with an uncoated engine.

\section{Smoke Emission}

Figure 11 shows that the variations in smoke level for different test conditions and indicating the smoke level as lower for a TBC engine with neat palm biodiesel as well as cerium oxide nanoparticles mixed palm biodiesel used conditions compared with a base engine. The average of reduction in the percentage of smoke emission by $35.25 \%, 45.15 \%$ and $53.76 \%$ respectively in neat palm biodiesel, 30 ppm and 60 ppm cerium oxide nanoparticles mixed palm biodiesel used TBC engine compared with a base engine (Venkata Ramanan and Yuvarajan, 2016). Higher combustion efficiency was maintained by TBC engine and oxidation catalyst of cerium oxide nanoparticles enhanced the complete combustion (Pandian et al., 2017).

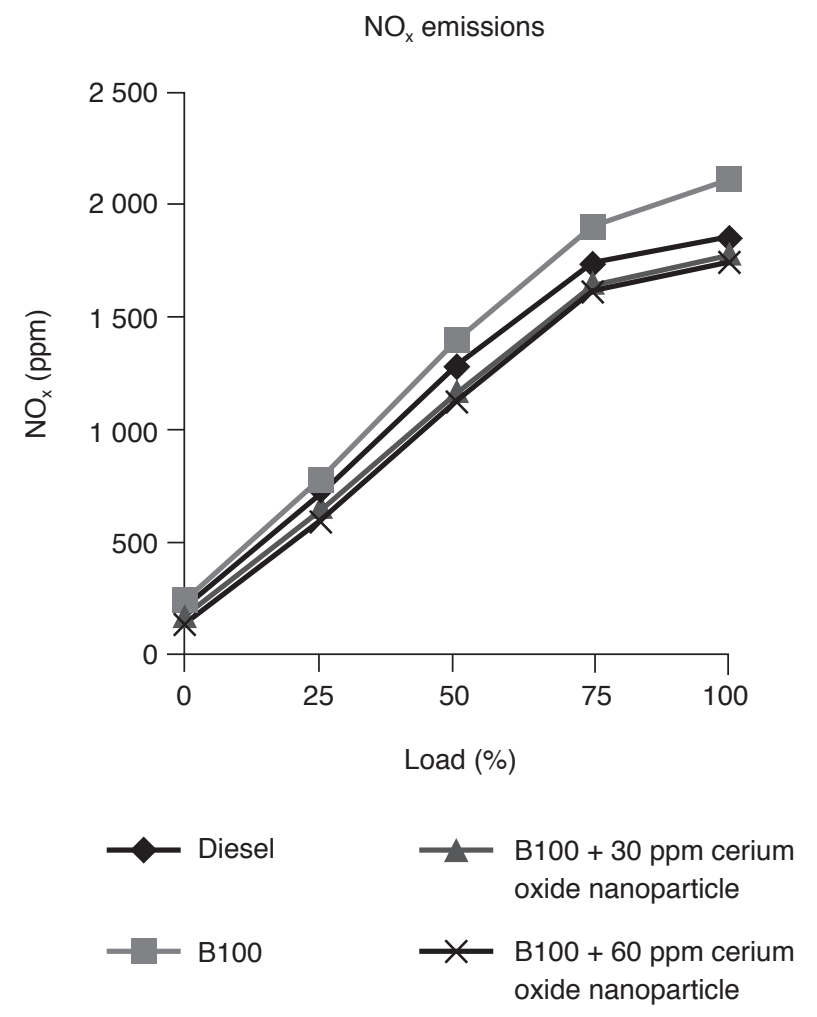

Figure 10. Variations in nitrogen oxide emission for test fuels with load.

\section{CONCLUSION}

The following single cylinder palm biodiesel engine performance and emission characteristics were seen using thermal barrier coating in the inner wall of the cylinder liner and piston head, and the addition of cerium oxide nanoparticles to palm biodiesel.

1) There is decrease in the SFC rate in the neat palm biodiesel, 30 ppm and 60 ppm cerium oxide mixed palm biodiesel used in TBC engine on an average as $11.86 \%, 16.92 \%$ and $20.57 \%$, respectively in all load conditions compared with a base engine.

2) BTE increased on an average by $3.21 \%, 4.28 \%$ and $4.82 \%$ respectively in the neat palm biodiesel, 30 ppm and 60 ppm mixed palm biodiesel used TBC engine under all load conditions compared with base engine.

3) Due to reduced incomplete combustion, combustion efficiency was high in TBC engine under different conditions and the carbon monoxide and hydrocarbon emissions level were very low compared with base engine.

4) Nitrogen oxide emission level was high in the neat palm biodiesel used TBC engine due to maintenance of high combustion temperature but it was reduced by the usage of 30 ppm and 60 ppm cerium oxide nanoparticles added to palm biodiesel in an average as $10.48 \%$ and $13.85 \%$, respectively compared with uncoated engine.

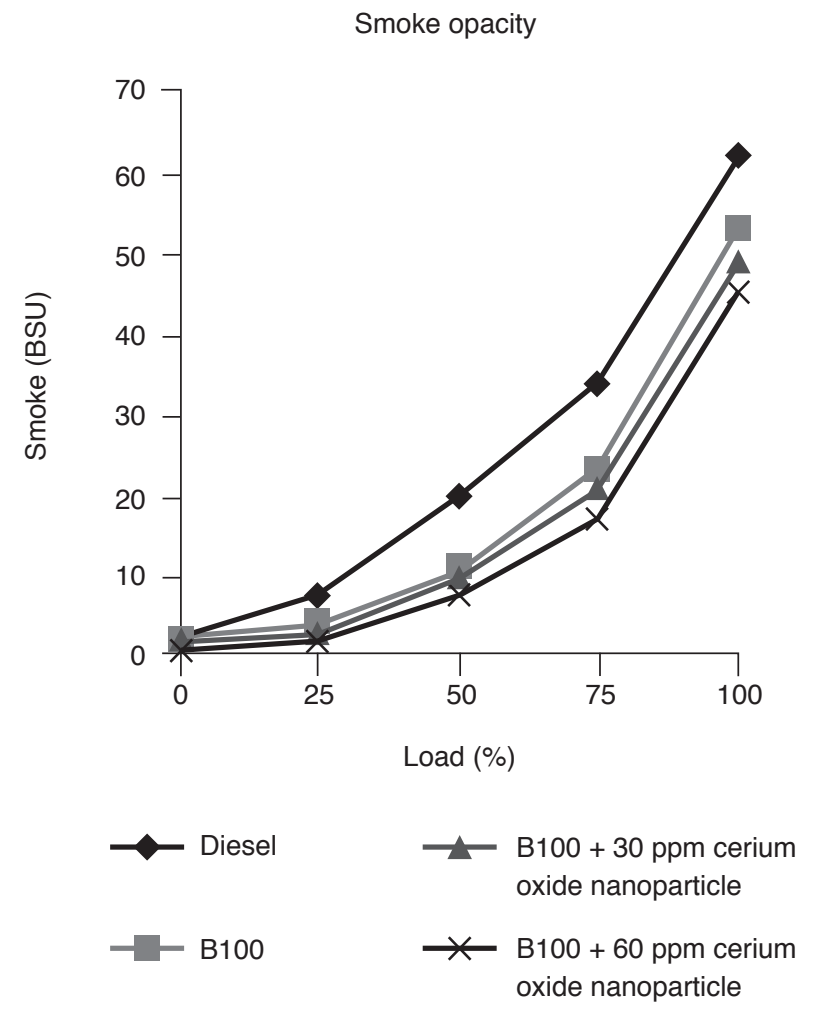

Figure 11. Variations in smoke emissions for test fuels with load. 
5) Smoke opacity level reduced level of neat palm biodiesel, $30 \mathrm{ppm}$ and $60 \mathrm{ppm}$ cerium oxide mixed palm biodiesel used TBC engine as $35.25 \%$, $45.15 \%$ and $53.76 \%$ respectively compared with base engine at full load condition.

\section{REFERENCES}

Anbarasu, A; Karthikeyan, A and Balaji, M (2015). Performance and emission characteristics of diesel engine using alumina nanoparticle blended biodiesel emulsion fuel. J. Energ. Resour. Technol., 138(2): 022203.

Anbarasu, A and Karthikeyan, A(2016). Performance and emission characteristics of a diesel engine using cerium oxide nanoparticle blended biodiesel emulsion fuel. J. Energy Engg., 142(1): 04015009.

Arul Gnana Dhas, A; Devarajan, Y and Nagappan, B (2018). Analysis of emission reduction in ethyne biodiesel-aspirated diesel engine. I. J. Green Energy, 15(7): 436-440.

Devarajan, Y; Munuswamy, D B; Nagappan, B and Pandian, A K (2018a). Performance, combustion and emission analysis of mustard oil biodiesel and octanol blends in diesel engine. Heat Mass Transfer Vol. 54 (6): 1803-1811. DOI:10.1007/s00231-0182274-X.

Devarajan, Y and Madhavan, V R (2017). Emission analysis on the influence of ferrofluid on rice bran biodiesel. J. Chilean Chem. Soc., 62(4): 3703-3707.

Devarajan, Y; Mahalingam, A; Munuswamy, D B and Nagappan, B (2018b). Emission and combustion profile study of unmodified research engine propelled with neat biofuels. Envi. Science Pollution Res. Vol. 25(20): 19643-19656. DOI:10.1007/ s11356-018-2137-5.

Devarajan, Y; Munuswamy, D B; Radhakrishnan, S; Mahalingam, A and Nagappan, B (2018c). Experimental testing and evaluation of neat biodiesel and heptanol blends in diesel engine. J. Testing Evaluation, 47(2): 20170307.

Joy, N; Devarajan, Y; Nagappan, B and Anderson, A (2017). Exhaust emission study on neat biodiesel and alcohol blends fueled diesel engine. Energy Sources, Part A: Recover, Utilization, Environ. Effects, 40: 115-119.
Kishore Pandian, A; Munuswamy, D B; Radhakrishana, S; Bathey Ramakrishnan, R B; Nagappan, B and Devarajan, Y (2017). Influence of an oxygenated additive on emission of an engine fueled with neat biodiesel. Petro. Sci., 14(4): 791-797.

Mahalingam, A; Munuswamy, D B; Devarajan, Y and Radhakrishnan, S (2018). Emission and performance analysis on the effect of exhaust gas recirculation in alcohol-biodiesel aspirated research diesel engine. Envi. Science Pollution Res., 25(13): 12641-12647.

Pandian, A K; Munuswamy, D B; Radhakrishanan, S; Devarajan, Y and Nagappan, B (2018). Emission and performance analysis of a diesel engine burning cashew nut shell oil biodiesel mixed with hexanol. Petro. Sci. Vol. 15(1): 176-184. DOI:10.1007/s12182017-0208-8.

Pandian, A K; Ramakrishnan, R B B and Devarajan, $Y$ (2017). Emission analysis on the effect of nanoparticles on neat biodiesel in unmodified diesel engine. Envi. Science Pollution Res., 24(29): 2327323278.

Radhakrishnan, S (2017). Emissions analysis on diesel engine fueled with palm oil biodiesel and pentanol blends. J. Oil Palm. Res. Vol. 29(3): 380-386.

Venkata Ramanan and Yuvarajan, D (2016). Emission analysis on the influence of magnetite nanofluid on methyl ester in diesel engine. Atmos. Pollu. Res., 7: 477-481.

Vellaiyan, S; Amirthagadeswaran, K S and Vijayakumar, S (2017). Combustion of stable waterin-diesel emulsion fuel and performance assessment. Energy Sources, Part A: Recover, Utilization, Environ. Effects, 39: 505-513.

Vellaiyan, S and Amirthagadeswaran, K S (2017). Emission characteristics of water-emulsified diesel fuel at optimized engine operation condition. Petro. Sci. Technol., 35: 1355-1363.

Yuvarajan, D; Pradeep, K and Magesh Kumar, S (2016a). Impact of oxygenated additives on performance characteristics of methyl ester in IC engine. Appl Mech. Mater., 852: 724-728.

Yuvarajan, D; Surendran, R; Vinoth Kumar, V and Devanathan, R (2016b). Role of additives on emission characteristics of methyl ester in constant speed diesel engine. Appl Mech. Mater., 852: 729-733. 